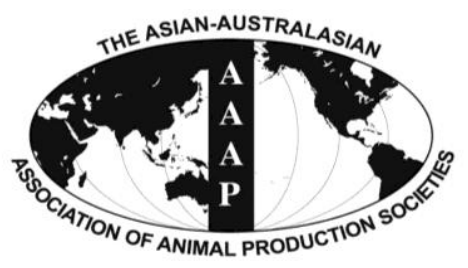

Asian-Aust. J. Anim. Sci.

Vol. 25, No. 5 : 635 - 641

May 2012

www.ajas.info

http://dx.doi.org/10.5713/ajas.2011.11336

\title{
Induction of Ski Protein Expression upon Luteinization in Rat Granulosa Cells
}

\author{
Hyun Kim ${ }^{1,2, *}$, Dong Hun Kim², Soo Bong Park ${ }^{2}$, Yeoung-Gyu Ko ${ }^{2}$, Sung-woo Kim², Yoon Jun Do², \\ Jae-Hong Park ${ }^{2}$ and Boh-Suk Yang ${ }^{3}$ \\ ${ }^{1}$ Department of Veterinary Physiology, Graduate School of Agricultural and Life Sciences, \\ The University of Tokyo, 1-1-1 Yayoi, Bunkyo-ku, Tokyo 113-8657, Japan \\ ${ }^{2}$ Animal Genetic Resources Station, National Institute of Animal Science, RDA, Namwon 590-832, Korea \\ ${ }^{3}$ Korean Native Cattle Experiment Station, National Institute of Animal Science, RDA, Pyeongchang 232-952, Korea
}

\begin{abstract}
Ski protein is implicated in proliferation/differentiation in a variety of cells. We had previously reported that Ski protein is present in granulosa cells of atretic follicles, but not in preovulatory follicles, suggesting that Ski has a role in apoptosis of granulosa cells. The alternative fate of granulosa cells other than apoptosis is to differentiate to luteal cells; however, it is unknown whether Ski is expressed and has a role in granulosa cells undergoing luteinization. Thus, the aim of the present study was to locate Ski protein in the rat ovary during luteinizationto predict the possible role of Ski. In order to examine the expression pattern of Ski protein along with the progress of luteinization, follicular growth was induced by administration of equine chorionic gonadtropin to immature female rats, and luteinization was induced by human chorionic gonadtropin treatment to mimic luteinizing hormone (LH) surge. While no Ski-positive granulosa cells were present in preovulatory follicle, Ski protein expression was induced in response to LH surge, and was maintained after the formation of the corpus luteum (CL). Though Ski protein is absent in granulosa cells of preovulatory follicle, its mRNA ( $c$-Ski) was expressed and the level was unchanged even after LH surge. Taken together, these results demonstrated that Ski protein expression is induced in granulosa cells upon luteinization, and suggests that its expression is regulated post-transcriptionally. (Key Words: Arkadia, Granulosa Cells, Luteinization, Ski)
\end{abstract}

\section{INTRODUCTION}

Ovarian folliculogenesis and luteinization in mammals is a complex series of events regulated by endocrine and paracrine/autocrine factors. Amongst the endocrine factors, the role of gonadotropins, follicle stimulating hormone (FSH) and luteinizing hormone (LH), in regulating folliculogenesis and luteinization is well established. Gonadotropin is an important survival factor for developing follicles in escaping atresia and stimulating early antral follicles to complete their final differentiation, reaching the preovulatory follicle stage. In response to the LH surge, a preovulatory follicle embarks on a terminal differentiation pathway, called "luteinization", that transforms granulosa and theca cells of a preovulatory follicle into luteal cells to form corpus luteum (CL). Luteinizing follicular cells

\footnotetext{
* Corresponding Author: Hyun Kim. Tel: +82-63-620-3562, Fax: +82-63-620-3592, E-mail: kimhyun7268@yahoo.co.kr Submitted Sept. 22, 2011; Accepted Nov. 23, 2011; Revised Feb. 2, 2012
}

undergo specific morphological and biochemical changes as well as endocrinological alterations in their transition to luteal cells (Roy et al., 1994; Smith et al., 1994). Many genes that are highly expressed in growing preovulatory follicles are turned off by the LH surge, whereas the expression of numerous genes that are involved in ovulation and luteinization increases dramatically during the periovulatory period (Espey et al., 2002; Richards et al., 2005).

The effects of gonadotropins are mediated or regulated by a number of paracrine/autocrine growth factors (Nilsson et al., 2002; Nilsson et al., 2003). For example, members of the transforming growth factor- $\beta$ (TGF- $\beta$ ) family are expressed by oocytes, granulosa cells, and theca cells in a developmental-stage dependent manner and play roles in proliferation/atresia of granulosa/theca cells, steroidogenesis, oocyte maturation, ovulation, and luteinization (Pehlivan et al., 2001; Juengel et al., 2005; Knight et al., 2006). The members of downstream signaling molecules (Smads) and 
binding proteins (follistatin) of TGF- $\beta$ family are also expressed in the ovary, and function in follicular development and luteinization (Drummond et al., 2002; Xu et al., 2002).

The signaling pathway of TGF- $\beta$ family is shown to be regulated by Ski, the protein encoded by proto-oncogene $c$ Ski (Li et al., 1986; Stavnezer et al., 1986; Nomura et al., 1989; Stavnezer et al., 1989; Sutrave et al., 1989), via its interactions with Smad proteins (Liu et al., 2001; Luo et al., 2003; Luo et al., 2004). The $c$-Ski, has been identified as the cellular homologue of $v$-Ski, that was originally identified as the transforming gene of the avian Sloan-Kettering viruses, which transform chicken embryonic fibroblasts, leading to their morphological transformation and anchorage-independent growth (Li et al., 1986; Stavnezer et al., 1986; Nomura et al., 1989; Stavnezer et al., 1989; Sutrave et al., 1989). In addition to its transforming activity, $c$-Ski is known to induce myogenic differentiation of quail embryonic cells (Li et al., 1986). Thus, $c$-Ski has been implicated to have dual roles in both regulating transformation (proliferation) and differentiation of cells.

We had previously shown that Ski is present in granulosa cells of atretic follicles in the rat ovary, while it is absent in those of preovulatory follicles (Kim et al., 2006). Since the TGF- $\beta$ family play important roles during luteinization, it is highly possible that Ski is involved in this process. Thus, the aim of the present study is, by means of immunohistochemical techniques, to locate Ski protein in the rat ovaries during ovulation and subsequent CL formation using the equine chorionic gonadtropin (eCG)/ human chorionic gonadtropin (hCG)-primed rat model in order to predict the possible involvement of Ski in luteinization.

\section{MATERIALS AND METHODS}

\section{Animals}

The immature (25 day old) female Wistar-Imamichi rats were purchased from the Imamichi Institute of Animal Reproduction (Ibaraki, Japan). Synchronized folliculogenesis was initiated by administration of of eCG (40 IU, s.c.) followed by hCG (15 IU, s.c.) to induce ovulaton and subsequent luteinization (Bell et al., 1968). In this model, ovulation occurs at around $12 \mathrm{~h}$ after hCG injection (Nothnick et al., 1996). The rats were killed by cervical dislocation and ovaries were collected at the time points indicated ( $\mathrm{n}=3-4$ animals per time point). After removal of connective tissues, ovaries were weighed, embedded in OCT compound (Sakura Finetechnical, Tokyo, Japan), and stored at $-80^{\circ} \mathrm{C}$ until use. In the experiment where gene expression was examined by real time PCR, granulosa cells were collected from the ovary and immediately used for RNA isolation. At each time point, blood samples were also collected, and the sera were separated and stored at $-20^{\circ} \mathrm{C}$. Atretic follicles were obtained from hypophysectomized female rats at $96 \mathrm{~h}$ after eCG treatment. All animals received humane care according to the Guide for the Care and Use of Animals of The University of Tokyo.

\section{Hormone assay}

Serum concentrations of estradiol-17! were measured by estradiol enzyme-immunoassay kits (Cayman Chemical, Ann Arbor, MI, USA), according to the manufacturer's protocol.

\section{Immunohistochemistry and TUNEL staining}

Immunohistochemical analyses of Ski were done as described previously (Kim et al., 2006). In brief, frozen tissue sections (5 $\mu \mathrm{m}$ thick) prepared from the OCTembedded rat ovary, mounted on glass slides, were fixed in $4 \%$ paraform aldehyde (PFA) in phosphate buffered-saline (PBS) for $20 \mathrm{~min}$, followed by incubation in $0.1 \%$ Triton $\mathrm{X}$ 100 in PBS for $15 \mathrm{~min}$. Then, the sections were immersed in blocking solution ( $8 \%$ skim milk in PBS) for $30 \mathrm{~min}$. The primary rabbit antibody specific for Ski (Santa Cruz Biotechnology, Santa Cruz, CA, USA; dilution 1:100 with 5\% normal goat serum (NGS) in PBS) was applied and incubated for $60 \mathrm{~min}$. After several washes with PBS, the sections were incubated with AlexaFluor-conjugated secondary antibody (Invitrogen, Carlsbad, CA, USA; dilution 1:200 with 5\% NGS in PBS) for $60 \mathrm{~min}$. Nuclei were counterstained with Hoechst33258. The sections were observed under the fluorescent microscope (BX50, Olympus, Tokyo, Japan) equipped with digital camera (DP70, Olympus, Tokyo, Japan). The proportions of Skipositive cells within luteinizing follicle/corpus luteum were calculated.

For double-staining of Ski and TUNEL-positive cells, the sections were fixed in $4 \%$ PFA in PBS for $30 \mathrm{~min}$, followed by incubation in $0.1 \%$ Triton X-100 in PBS for 15 min. The sections were incubated in methanol for $30 \mathrm{~min}$, then immersed in blocking solution (8\% skim milk in PBS) for $30 \mathrm{~min}$. The primary antibody specific for Ski was applied and incubated for $90 \mathrm{~min}$. The sections were incubated with AlexaFluor-conjugated secondary antibody (Invitrogen) for $60 \mathrm{~min}$. DNA fragmentation was subsequently detected by commercial kit (In Situ Cell Detection Kit, Fluorescein, Roche, Penzberg, Germany). The slides were rinsed with PBS, and incubated with permeabilisation solution $(0.1 \%$ Triton $\mathrm{X}-100$ in $0.1 \%$ sodium citrate) for $2 \mathrm{~min}$ on ice. The slides were incubated with TdT (Fluorescein, green color) for $60 \mathrm{~min}$ at $37^{\circ} \mathrm{C}$. The sections were observed under the fluorescent microscope 
(BX50, Olympus, Tokyo, Japan) equipped with digital camera (DP70, Olympus, Tokyo, Japan).

\section{qPCR (real time PCR)}

Granulosa cells were obtained at 0, 3, 6 and $12 \mathrm{~h}$ after hCG-injection by puncturing the large preovulatory follicles with a 27-gauge needle. The cells were washed with PBS and immediately used for RNA isolation.

Total RNA was isolated using Trizol reagent (Invitrogen), and cDNA was synthesized by SuperScript II (200 U/ml) with oilgo-dT 16 primer. qPCR was done using with LightCycler (Roche Diagonostics GmbH, Mannheim, Germany) and LightCycler FastStart Thunderbird SYBR qPCR Mix (Toyobo, Osaka, Japan) according to the manufacturer' instructions. The primer sequences used were as follows: rat c-ski (forward primer; 5' CAGCAGATC AACTCGGTGTG-3' reverse primer; 5'AGGATGCCCAT GACTTTGAG-3', rat arkadia (forward primer; 5' CGTGA GGAGAACTGCATCAA-3' reverse primer; 5' GGATGTG CTAATGCATGCTG -3' and rat HPRT (forward primer; 5' GACCGGTTCTGTCATGTCG-3' reverse primer; 5' ACCT GGTTCATCATCACTAATCAC -3'. Rat-specific primers were designed using PRIMER3 software (available at http://fokker.wi.mit.edu/primer3/), and the specificity for each primer set was confirmed by both electrophoresis of the PCR products and analyzing the melting (dissociation) curve after each qPCR. Twenty microlitter of the reaction solution consisted of $2 \mu$ l of the template (appropriate dilution was determined by gene), $10 \mu$ of LightCycler FastStart Thunderbird SYBR qPCR Mix, $1 \mu \mathrm{l}$ of $10 \mu \mathrm{M}$ of each primer and $3 \mu$ l of diethylpyrocarbonate-treated water. PCR amplification was performed as follows: pre-denature for one cycle at $95^{\circ} \mathrm{C}$ for $15 \mathrm{~min}$ and 45 cycles at $95^{\circ} \mathrm{C}$ for $15 \mathrm{~s}, 59^{\circ} \mathrm{C}$ for $20 \mathrm{~s}$ and $72^{\circ} \mathrm{C}$ for $30 \mathrm{~s}$. Melting curve analysis was performed at 65 to $95^{\circ} \mathrm{C}$ with $0.1^{\circ} \mathrm{C} / \mathrm{s}$ temperature transition.

\section{Statistical analysis}

Statistical analyses were conducted using StatView (version J5, Abacus Concepts, Inc. CA). One-way analysis of variance and Dunnett' test were used to determine differences between the groups. Differences were considered statistically significant at $\mathrm{p}<0.05$.

\section{RESULTS}

To investigate the possible involvement of Ski during luteinization, immunohistochemical analysis of Ski was performed on ovarian sections obtained from rats having single generation of CL. Consistent with previous reports (Bell et al., 1968), ovarian weights were significantly higher in the rats treated with eCG only and primed with eCG/hCG
A

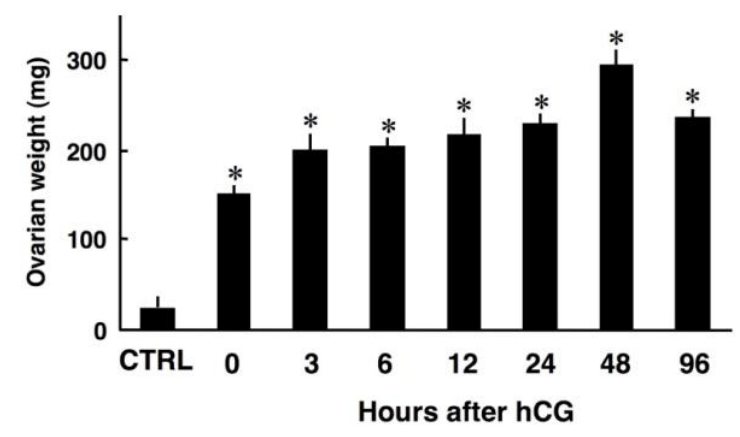

B

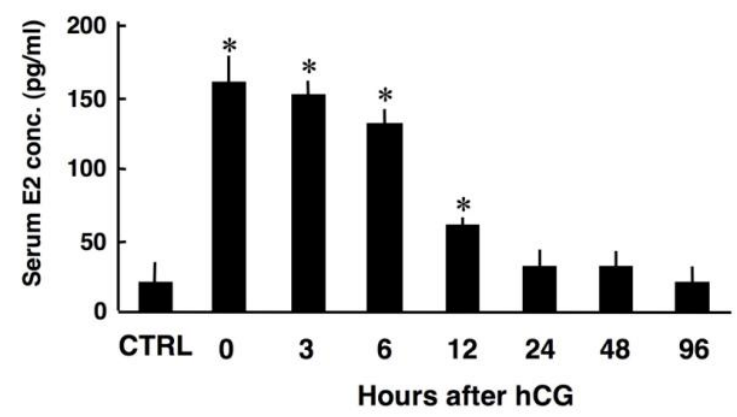

Figure 1. Changes in ovarian weights (A) and serum estradiol-17 $\beta$ concentrations (B). CTRL, control (without hormonal treatment). The data are means $\pm \operatorname{SE}(n=3) .{ }^{*} \mathrm{p}<0.01$ vs. CTRL.

than in the control rats, indicating that eCG and hCG treatment successfully induced follicular growth, ovulation and luteinization (Figure 1A). Serum estradiol concentrations were higher in the rats treated with eCG only and primed with eCG/hCG than in the control rats until $12 \mathrm{~h}$ after hCG injection (Figure 1B). Thereafter, estradiol concentration decreased to a level comparable to that in control rats, representing the decreased aromatase activity due to an initiation of luteinization (Figure 1B). These results indicate the successful treatment with eCG and hCG to establish a rat model having single generation of CL.

Then, we performed immunohistochemical analyses of Ski on ovarian sections from eCG/hCG treated rats. As shown in Figure 2A, Ski was expressed in luteinizing granulosa cells at 6 and $12 \mathrm{~h}$ after hCG injection, while no Ski-positive granulosa cells were found in preovulatory follicles ( $0 \mathrm{~h}$ in Figure 2A). Ski expression was persisted after the formation of CL (96 h after hCG) (Figure 2A). Quantitative analysis revealed that the proportion of Skipositive cells at $24 \mathrm{~h}$ or later after hCG injection was significantly higher than that of the previous time points (before $12 \mathrm{~h}$ ) (Figure 2B). Since ovulation in this rat model is expected to occur at around $12 \mathrm{~h}$, this result suggests that the number of Ski-positive cells increases after ovulation.

We had previously reported the presence of Ski protein in granulosa cells of atretic follicles (Kim et al., 2006). In order to examine if Ski-positive cells appeared after hCG treatment are the cells undergoing apoptosis, TUNEL was 
A
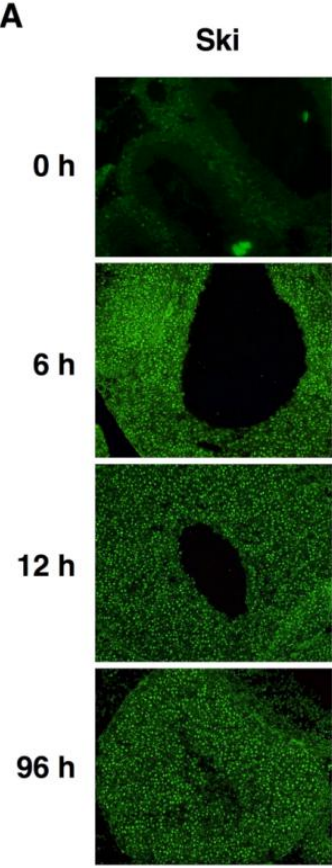

Hoechst
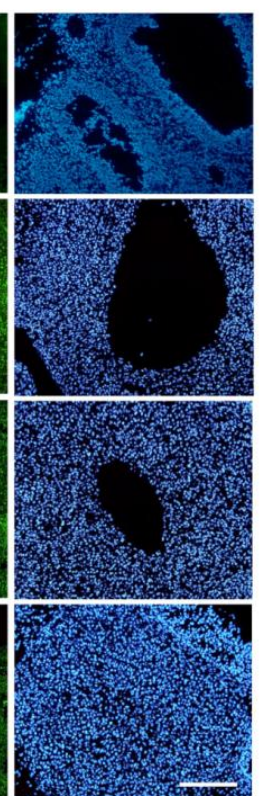

B

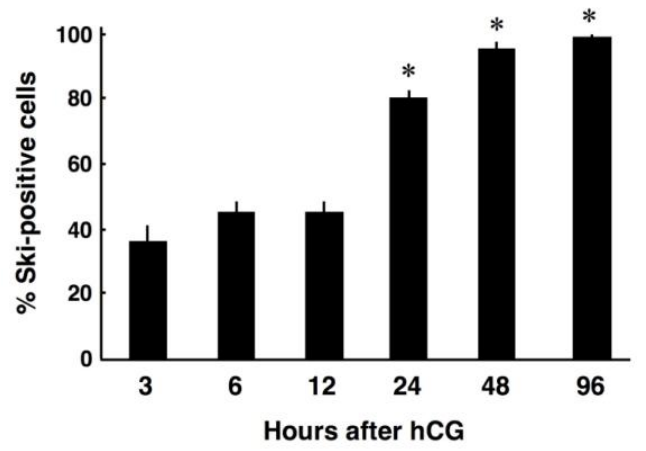

Figure 2. Immunohistochemistry of Ski. (A) Time (h) indicates hours after hCG injection. Note the absence of Ski-positive granulosa cells in preovulatory follicle $(0 \mathrm{~h})$. Scale bar $=400 \mu \mathrm{m}$. (B) Quantitative analyses of Ski-positive cells. The data are expressed as proportions of Ski positive cells. The data are means \pm SE $(n=6) .{ }^{*} p<0.01$ vs. hCG 3,6 and $12 \mathrm{~h}$.

performed. No apoptotic cell death was detected during luteinization whereas Ski-positive cells were present (Figure 3). On the other hand, a numerous number of TUNEL-positive cells were observed in atretic follicle containing Ski-positive cells (Figure 3). Taken together, these results clearly exclude the possible presence of Ski-

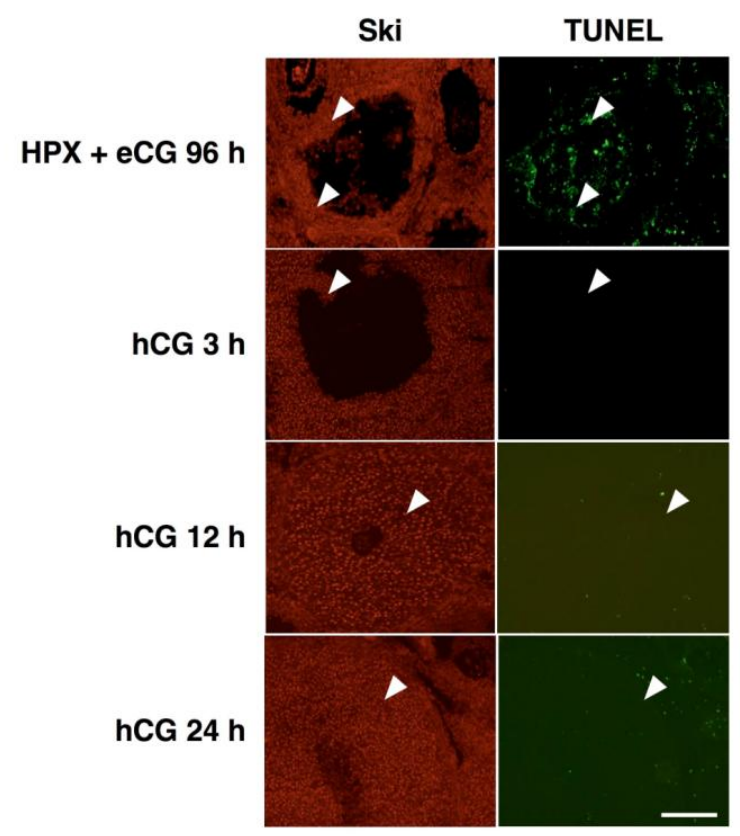

Figure 3. Immunohistochemistry of Ski and TUNEL staining. Note the presence of Ski and TUNEL double-positive cells only in atretic follicle (HPX+eCG 96 h). Scale bar $=400 \mu \mathrm{m}$. positive cells that are dying during CL formation, and suggested that Ski expression is induced in granulosa cells upon luteinization.

In order to examine if $c$-Ski expression is under the control of LH, luteinizing granulosa cells were obtained

$$
\text { A }
$$

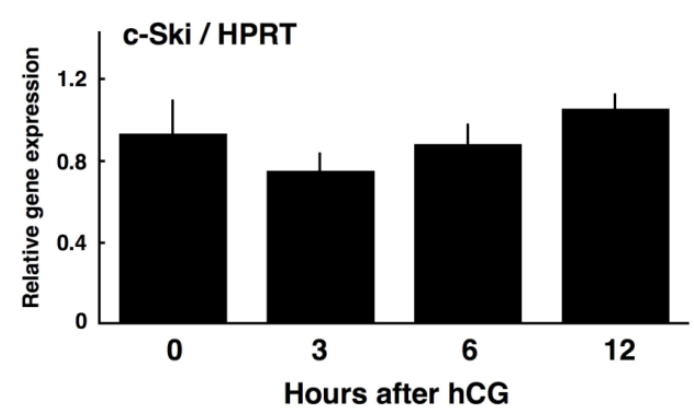

B

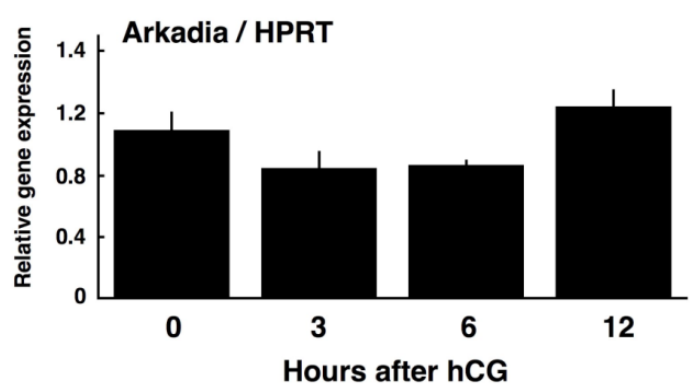

Figure 4. qPCR analyses of $c$-Ski (A) and Arkadia (B). Relative expression levels to HPRT were calculated and graphed. The data are means $\pm \operatorname{SE}(n=3-4)$. 
from eCG/hCG-primed rats before ovulation, and their expression of $c$-Ski mRNA was determined by qPCR. Unexpectedly, $c$-Ski mRNA was present in granulosa cells even before hCG injection, and its expression level was unchanged after hCG injection (Figure 4A), indicating that $c$-Ski mRNA expression in granulosa cells is not regulated during luteinization. This raises the possibility that the amount of Ski protein is regulated at the translational and/or post-translational, not transcriptional, level during luteinization.

Recently, Nagano et al. (2010) reported that knockdown of Arkadia, an E3 ubiquitin ligase, abrogated TGF- $\beta$ induced degradation of Ski protein, demonstrating that Arkadia is responsible for the degradation of Ski protein. Thus, in order to examine the possible involvement of Arkadia in the regulation of Ski protein, the expression level of Arkadia mRNA during luteinization of granulosa cells was assessed by qPCR. As shown in Figure 4B, the level of Arkadia mRNA expression was unchanged during luteinization.

\section{DISCUSSION}

The results of the present study demonstrated the presence of Ski protein in luteinizing granulosa cells and cells within the CL, suggesting the possible involvement of Ski during luteinization and in the maintenance of CL function.

The present study suggested that the number of Skipositive cells increases after ovulation. During luteinization, the steroidogenic granulosa and theca cells differentiate to luteal steroidogenic cells, and upon ovulation, other nonsteroidogenic cell populations such as fibroblast, endothelial, blood, immune cells migrate extensively into the newly formed CL. These non-steroidogenic cells are shown to be essential for luteinization and maintenance of CL function (Enders et al., 1962; Meyer et al., 1980; Rodgers et al., 1984; O'Shea et al., 1989; Matsuyama et al., 1992; Nelson et al., 1992; Yamanouchi et al., 1992; Brännström et al., 1994; Matsuyama et al., 1995). In this regard, it should be noted that Ski is shown to be present and have roles in macrophages (Ueki et al., 2008). Thus, it is possible that Ski may have role in the non-steroidogenic cells migrated at the time of ovulation.

The process of luteinization is regarded to be under the control of luteinization inhibitors, which are thought to act to prevent rapid luteinization and suppress progesterone synthesis until the oocyte is released at ovulation (Knight et al., 2006). Granulosa cells secrete activin, which stimulates granulosa cell proliferation in preantral/early antral follicles (Zhao et al., 2001), and up-regulates FSH receptors and FSH-induced aromatase activity (Xiao et al., 1992a; Xiao et al., 1992b). Besides activin, BMP-4, BMP-7, BMP-6,
BMP-15, and GDF-9 (Nilsson et al., 2002; Nilsson et al., 2003; McNatty et al., 2005) enhance estradiol and inhibin secretion by granulosa cells while suppressing progesterone secretion. After ovulation and during CL formation, inhibin/activin subunit expression is down-regulated in most species. A recent study also showed that follicular expressions of BMP-2, BMP-3, BMP-4, BMP-6, and BMP7 are profoundly reduced upon ovulation (Erickson et al., 2003). These reports suggest that these TGF- $\beta$ family proteins have roles in delaying follicular atresia and/or luteinization. Thus, considering that Ski negatively regulates the activity of TGF- $\beta$ family proteins, it is possible that Ski, whose expression is up-regulated in granulosa cells, may favor luteinization by bioneutralizing intrafollicular activity of these proteins.

Several studies indicated that transcripts of Ski, $c$-Ski, are ubiquitously expressed in many tissues and mRNA levels are relatively constant during cell cycle, differentiation, and embryogenesis (Grimes et al., 1993; Ambrose et al., 1995). The result of the present study that $c$-Ski expression was unchanged during luteinization of granulosa cells is in agreement with these reports. Thus, we speculated that the regulated ubiquitin-proteasome system is one of the possible mechanism to control Ski protein level during luteinization. Based on the recent findings that degradation of Ski protein is mediated by an E3 ubiquitin ligase, Arkadia (Nagano et al., 2007), we examined if Arkadia expression is changed during luteinization of granulosa cells. The result demonstrated that Arkadia is indeed expressed in grannulosa cells but its expression is unchanged. However, this does not exclude the possibility that Arkadia is involved in regulating Ski protein during luteinization of granulosa cells since we currently have no data on the Arkadia protein expression due to an unavailability of rat Arkadia-specific antibody. Alternatively, it is also possible that other ubiquitin ligases, including Smad ubiquitin regulatory factors, Smurf1 and Smurf2, and the APC/Cdh1 complex (Kavsak et al., 2000; Ebisawa et al., 2001; Episkopou et al., 2001; Hanyu et al., 2001), are the candidates to regulate Ski protein level in granulosa cells. Therefore, the issue regarding the regulatory mechanism of Ski protein expression level awaits for further investigation.

In conclusion, the present study demonstrated that Ski protein expression is induced in granulosa cells upon luteinization, suggesting that Ski is involved in luteinization and the maintenance of CL function. In addition, it was suggested that the amount of Ski protein is regulated at the post-transcriptional level.

\section{ACKNOWLEDGEMENTS}

This work was supported by 2011 PostDoctoral Fellowship Program (PJ008240022012) of National 
Institute of Animal Science, Rural Development Adminstration, Republic of Korean.

\section{REFERENCES}

Ambrose, M. R., M. E. Bottazzi and M. M. Goodenow. 1995. Expression of the $c$-Ski proto-oncogene during cell cycle arrest and myogenic differentiation. DNA Cell Biol. 14:701-707.

Bell, E. T. and S. F. Lunn. 1968. The induction of ovulation in immature rats treated with pregnant mares'serum gonadotrophin and human chorionic gonadotrophin. J. Exp. Physiol. Cogn. Med. Sci. 53:129-135.

Brännström, M., L. Giesecke, I. C. Moore, C. J. van den Heuvel and S. A. Robertson. 1994. Leukocyte subpopulations in the rat corpus luteum during pregnancy and pseudopregnancy. Biol. Reprod. 50:1161-1167.

Drummond, A. E., M. T. Le, J. F. Ethier, M. Dyson and J. K. Findlay. 2002. Expression and localization of localization of activin receptors, Smads, and beta glycan to the postnatal rat ovary. Endocrinology 143:1423-1433.

Ebisawa, T., M. Fukuchi, G. Murakami, T. Chiba, K. Tanaka, T. Imamura and K. Miyazono. 2001. Smurf1 interacts with transforming growth factor-beta type I receptor through Smad7 and induces receptor degradation. J. Biol. Chem. 276:1247712480.

Enders, A. C. 1962. Observations on the fine structure of lutein cells. J. Cell Biol. 12:101-113.

Episkopou, V., R. Arkell, P. M. Timmons, J. J. Walsh, R. L. Andrew and D. Swan. 2001. Induction of the mammalian node requires Arkadia function in the extraembryonic lineages. Nature 410:825-830.

Erickson, G. F. and S. Shimasaki. 2003. The spatiotemporal expression pattern of the bone morphogenetic family in rat ovary cell types during the estrous cycle. Reprod. Biol. Endocrinol. 1:9.

Espey, L. L. and J. S. Richards. 2002. Temporal and spatial patterns of ovarian gene transcription following an ovulatory dose of gonadotropin in the rat. Biol. Reprod. 67:1662-1670.

Grimes, H. L., M. R. Ambrose and M. M. Goodenow. 1993. c-Ski transcripts with and without exon 2 are expressed in skeletal muscle and throughout chick embryogenesis. Oncogene 8: 2863-2868.

Hanyu, A., Y. Ishidou, T. Ebisawa, T. Shimanuki, T. Imamura and K. Miyazono. 2001. The N domain of Smad7 is essential for specific inhibition of transforming growth factor-beta signaling. J. Cell Biol. 155:1017-1027.

Juengel, J. L. and K. P. McNatty. 2005. The role of proteins of the transforming growth factor-beta superfamily in the intraovarian regulation of follicular development. Hum. Reprod. 11:143-160.

Kavsak, P., R. K. Rasmussen, C. G. Causing, S. Bonni, H. Zhu, G. H. Thomsen and J. L. Wrana. 2000. Smad7 binds to Smurf2 to form an E3 ubiquitin ligase that targets the TGF beta receptor for degradation. Mol. Cell 6:1365-1375.

Kim, H., K. Yamanouchi and M. Nishihara. 2006. Expression of ski in the granulosa cells of atretic follicles in the rat ovary. J. Reprod. Dev. 52:715-721.
Knight, P. G. and C. Glister. 2006. TGF-beta superfamily members and ovarian development. Reproduction 132:191-206.

Liu, X., Y. Sun, R. A. Weinberg and H. F. Lodish. 2001. Ski/Sno and TGF-beta signaling. Cytokine Growth Factor Rev. 12:1-8.

Li, Y., C. M. Turck, J. K. Teumer and E. Stavnezer. 1986. Unique sequence, Ski, in Sloan-Kettering avian retroviruses with properties of a new cell-derived oncogene. J. Virol. 57:10651072.

Luo, K. 2003. Negative regulation of BMP signaling by the ski oncoprotein. J. Bone Joint Surg. Am. 3:39-43.

Luo, K. 2004. Ski and SnoN: negative regulators of TGF-beta signaling. Curr. Opin. Genet. Dev. 14:65-70.

Matsuyama, S. and M. Takahashi. 1995. Immunoreactive (ir)transforming growth factor (TGF)-beta in rat corpus luteum: ir-TGF beta is expressed by luteal macrophages. Endocr. J. 42: 203-217.

Matsuyama, S, K. Shiota, C. Tachi, M. Nishihara and M. Takahashi. 1992. Splenic macrophages enhance prolactin and luteinizing hormone action in rat luteal cell cultures. Endocrinol. Jpn. 39:51-57.

McNatty, K. P., J. L. Juengel, K. L. Reader, S. Lun, S. Myllymaa, S. B. Lawrence, A. Western, M. F. Meerasahib, D. G. Mottershead, N. P. Groome, O. Ritvos and M. P. Laitinen. 2005. Bone morphogenetic protein 15 and growth differentiation factor 9 co-operate to regulate granulosa cell function in ruminants. Reproduction 129:481-487.

Meyer, G. T. and N. W. Bruce. 1980. Quantitative cell changes and vascularisation in the early corpus luteum of the pregnant rat. Anat. Rec. 197:369-374.

Nagano, Y., D. Koinuma, K. Miyazawa and K. Miyazono. 2010. Context-dependent regulation of the expression of $c$-Ski protein by Arkadia in human cancer cells. J. Biochem. 147:545-554.

Nagano, Y., K. J. Mavrakis, K. L. Lee, T. Fujii and D. Koinuma, H. Sase, K. Yuki, K. Isogaya, M. Saitoh, T. Imamura, V. Episkopou, K. Miyazono and K. Miyazawa. 2007. Arkadia induces degradation of $S n o N$ and $c-S k i$ to enhance transforming growth factor-beta signaling. J. Biol. Chem. 282: 20492-501.

Nelson, S. E., M. P. McLean, P. G. Jayatilak and G. Gibori. 1992. Isolation, characterization, and culture of cell subpopulations forming the pregnant rat corpus luteum. Endocrinology 130: 954-966.

Nilsson, E. E. and M. K. Skinner. 2002. Growth and differentiation factor-9 stimulates progression of early primary but not primordial rat ovarian follicle development. Biol. Reprod. 67: 1018-1024.

Nilsson, E. E. and M. K. Skinner. 2003. Bone morpfogenetic protein-4 acts as an ovarian follicle survival factor and promotes primordial follicle development. Biol. Reprod. 69: 1265-1272.

Nomura, N., S. Sasamoto, S. Ishii, T. Date, M. Matsui and R. Ishizaki. 1989. Isolation of human cDNA clones of Ski and the Ski-related gene, Sno. Nucleic Acids Res. 17:5489-5500.

Nothnick, W. B. and T. E. Curry Jr. 1996. Divergent effects of interleukin-1 beta on steroidogenesis and matrix metalloproteinase inhibitor expression and activity in cultured rat granulosa cells. Endocrinology 137:3784-3790. 
O'Shea, J. D., R. J. Rodgers and M. J. D'Occhio. 1989. Cellular composition of the corpus luteum of the cow. J. Reprod. Fertil. 85:483-487.

Pehlivan, T., A. Mansour, R. Z. Spaczynski and A. J. Duleba. 2001. Effects of transforming growth factor-alpha and-beta on proliferation and apoptosis of rat theca-interstitial cells. J. Endocrinol. 170:639-645.

Richards, J. S., I. Hernandez-Gonzalez, I. Gonzalez-Robayna, E. Teuling, Y. Lo, D. Boerboom, A. E. Falender, K. H. Doyle, R. G. LeBaron, V. Thompson and J. D. Sandy. 2005. Regulated expression of ADAMTS family members in follicles and cumulus oocyte complexes: evidence for specific and redundant patterns during ovulation. Biol. Reprod. 72:12411255.

Rodgers, R. J., J. D. O'Shea and N. W. Bruce. 1984. Morphometric analysis of the cellular composition of the ovine corpus luteum. J. Anat. 138:757-770.

Roy, S. K. and J. Hughes. 1994. Ontogeny of granulosa cells in the ovary: lineage-specific expression of transforming growth factor beta 2 and transforming growth factor beta 1 . Biol. Reprod. 51:821-830.

Smith, M. F., E. W. McIntush and G. W. Smith. 1994. Mechanisms associated with corpus luteum development. J. Anim. Sci. 72: 1857-1872.

Stavnezer, E., A. E. Barkas, L. A. Brennan, D. Brodeur and Y. Li. 1986. Transforming Sloan-Kettering viruses generated from the cloned $\mathrm{v}$-ski oncogene by in vitro and in vivo recombinations. J. Virol. 57:1073-1083.
Stavnezer, E., D. Brodeur and L. Brennan. 1989. The $v$-Ski oncogene encodes a truncated set of $c$-Ski coding exons with limited sequence and structural relatedness to $v-m y c$. Mol. Cell Biol. 9:4038-4045.

Sutrave, P., S. H. Hughes. 1989. Lsolation and characterization of three distinct cDNAs for the chicken $c$-Ski gene. Mol. Cell Biol. 9:4046-4051

Ueki, N., L. Zhang and M. J. Hayman. 2008. Ski can negatively regulates macrophage differentiation through its interaction with PU.1. Oncogene 27:300-307.

Xiao, S., P. G. Farnworth and J. K. Findlay. 1992a. Interation between activin and follicle-stimulating hormone-suppressing protein/follistatin in the regulation of basal inhibin production by cultured rat granulosa cells. Endocrinology 131:2365-2370.

Xiao, S., D. M. Robertson and J. K. Findlay. 1992b. Effects of activin and follicle-stimulating hormone (FSH)-suppressing protein/follistatin on FSH receptors and differentitation of cultured rat granulosa cells. Endocrinology 131:1009-1016.

$\mathrm{Xu}$, J., J. Oakley and E. A. McGee. 2002. Stage-specific expression of Smad2 and Smad3 duringfolliculogenesis. Biol. Reprod. 66:1571-1578.

Yamanouchi, K., S. Matsuyama, M. Nishihara, K. Shiota, C. Tachi and M. Takahashi. 1992. Splenic macrophages enhance prolactin-induced progestin secretion from mature rat granulosa cells in vitro. Biol. Reprod. 46:1109-1113.

Zhao, J., M. A. Taverne, G. C. van der Weijden, M. M. Bevers and R. van den Hurk. 2001. Effect of activin A on in vitro development of rat preantral follicles and localization of activin A and activin receptor II. Biol. Reprod. 65:967-977. 